\title{
PENGARUH VARIASI SUHU DAN LAMA PENYIMPANAN TERHADAP VIABILITAS BAKTERI ASAM LAKTAT (BAL) DAN NILAI PH YOGHURT
}

\section{The Effect Of Temperature Variation And Storage Time On The Viability Of Latic Acid Bacteria (Lab) And Ph Value Of Yoghurt}

\author{
Aditya Dimas Pangestu ${ }^{{ }^{*}}$ \\ Kurniawan ${ }^{2}$ \\ Supriyadi $^{3}$ \\ *,Universitas Muhammadiyah \\ Purwokerto, Indonesia \\ 2, Universitas Muhammadiyah \\ Purwokerto, Indonesia \\ 3. Universitas Muhammadiyah \\ Purwokerto, Indonesia \\ *email: adityadipaa@gmail.com
}

\begin{abstract}
Abstrak
Semakin meningkatnya kesadaran masyarakat akan pola hidup sehat menyebabkan banyak masyarakat mengkonsumsi yoghurt. Yoghurt merupakan produk olahan susu yang difermentasi dengan menambahkan konsentrat susu skim yang telah dipasteurisasi dan ditambahkan kultur bakteri asam laktat ke dalamnya. Kultur bakteri yang umum digunakan dalam produksi yoghurt adalah bakteri $L$. casei yang berperan memecah laktosa menjadi asam laktat. Untuk menjaga kualitas yoghurt, umumnya yoghurt disimpan pada suhu rendah, namun faktanya, masih banyak pelaku usaha yang hanya menyimpannya di dalam cool box atau suhu ruang. Tujuan penelitian ini adalah untuk mengetahui gambaran viabilitas BAL serta pengaruh variasi suhu dan lama penyimpanan terhadap viabilitas $\mathrm{BAL}$ dan nilai $\mathrm{pH}$ pada yoghurt. Penelitian ini menggunakan metode eksperimental dengan Rancangan Acak Lengkap (RAL) dengan 3 perlakuan berupa variasi suhu penyimpanan yaitu suhu $5^{\circ} \mathrm{C}, 15^{\circ} \mathrm{C}$, dan $25^{\circ} \mathrm{C}$ masing-masing perlakuan suhu disimpan selama I minggu, 2 minggu, 3 minggu, dan 4 minggu. Penelitian ini dilakukan pada bulan Desember 2020. Hasil penelitian menunjukan bahwa nilai viabilitas tertinggi $\left(289 \times 10^{6} \mathrm{CFU} / \mathrm{mL}\right)$ bakteri asam laktat pada yoghurt diperoleh pada suhu $5^{\circ} \mathrm{C}$ dengan lama penyimpanan dua minggu. Nilai $\mathrm{pH}$ yoghurt dipengaruhi oleh suhu dan lama waktu penyimpanan, semakin tinggi suhu dan lama waktu penyimpanan, maka menyebabkan nilai $\mathrm{pH}$ yoghurt semakin turun. Kesimpulan yang dapat diambil dari penelitian ini adalah viabilitas tertinggi $\mathrm{BAL}$ diperoleh pada suhu $5^{\circ} \mathrm{C}$ dengan waktu simpan dua minggu, sedangkan nilai $\mathrm{pH}$ yoghurt terbaik dicapai pada suhu $5^{\circ} \mathrm{C}$ selama satu minggu.
\end{abstract}

\section{Kata Kunci:}

Yoghurt

Viabilitas

Suhu

Bakteri asam laktat

\section{Keywords:}

Yogurt

Viability

Temperature

Lactic acid bacteria

\begin{abstract}
Consuming yogurt indicates the increasing public awareness of healthy lifestyles has led many people to consume yogurt. Yogurt is a fermented milk product by adding pasteurized skim milk concentrate and adding lactic acid bacteria culture. $L$. casei is the bacterial culture that is commonly used in the production of yogurt is, which has a role in breaking down lactose into lactic acid. To maintain its quality, yogurt is generally stored at a low temperature, but in fact, there are still many business actors who only store it in a cool box or even at room temperature. The purpose of this study was to describe the viability of $L A B$ and the effect of variations in temperature and storage time on the viability of $\angle A B$ and $\mathrm{pH}$ value of yogurt. This study used an experimental method with a completely randomized design (CRD) with 3 treatments in the form of variations in storage temperature, namely $5^{\circ} \mathrm{C}, 15^{\circ} \mathrm{C}$, and $25^{\circ} \mathrm{C}$, each treatment temperature was stored for I week, 2 weeks, 3 weeks, and 4 weeks. This study was conducted in December 2020. The results showed that the highest viability value $(289 \times 106 \mathrm{CFU} / \mathrm{mL})$ of lactic acid bacteria in yogurt was obtained at $5^{\circ} \mathrm{C}$ with a storage time of two weeks. Yogurt $\mathrm{pH}$ value is influenced by temperature and storage time, the higher the temperature and storage time, it causes the yogurt $\mathrm{pH}$ value to decrease. The conclusion that can be drawn from this study is that the highest viability of $L A B$ was obtained at $5^{\circ} \mathrm{C}$ with a shelf life of two weeks, while the best $\mathrm{pH}$ value of yogurt was achieved at $5^{\circ} \mathrm{C}$ for one week.
\end{abstract}

\section{PENDAHULUAN}

Yoghurt merupakan produk olahan susu yang difermentasi dengan menambahkan konsentrat susu skim yang telah dipasteurisasi atau disterilkan, kemudian ditambahkan kultur bakteri asam laktat ke dalamnya. Kultur bakteri yang umum digunakan dalam produksi yoghurt adalah bakteri $S$. thermophilus, $L$. 
bulgaricus, dan L. Casei. Bakteri ini memiliki peran memecah laktosa pada susu menjadi asam laktat (Wulandari \& Putranto, 2010).

Meningkatnya kesadaran masyarakat akan menjaga pola hidup sehat dengan cara mengkonsumsi yoghurt semakin meningkat, hal ini dikarenakan Yoghurt merupakan susu fermentasi yang memiliki kandungan zat gizi yang lengkap dan baik bagi kesehatan. Dalam mengkonsumsi yoghurt terdapat manfaat yang dihasilkan bagi tubuh antara lain mengatur saluran pencernaan, antidiare, antikanker, meningkatkan pertumbuhan, membantu penderita lactose intolerance dan mengatur kadar kolesterol dalam darah, mereduksi tumor dan kanker pada saluran pencernaan, dapat melawan pertumbuhan bakteri patogen di dalam saluran pencernaan, stimulasi pembuangan kotoran, mengandung kalsium yang sangat baik untuk kesehatan tulang dan dapat mencegah terjadinya osteoporosis (Syainah et al. 20l4) (Wirawati, 2019) (Aswal et al. 20I2).

Selain itu, yoghurt dapat diperoleh dengan mudah di supermarket maupun toko-toko di sekitar rumah, memiliki tekstur yang lembut dan banyak varian rasa seperti rasa susu (plain), coklat, strawberi, jeruk, apel, anggur dan lainya sehingga mudah diterima dan digemari oleh semua kalangan. Sebagai makanan yang mengandung bakteri hidup, yoghurt harus disimpan pada tempat khusus agar kualitasnya tetap terjaga dengan baik dan terhindar dari kerusakan dan juga kontaminasi dari lingkungan.

Faktor lingkungan yang penting dan dapat mempengaruhi kualitas yoghurt adalah suhu dan lama penyimpanan yang berpengaruh terhadap kelangsungan hidup BAL dalam yoghurt. Umumnya, setiap produsen yoghurt telah mencantumkan kisaran suhu penyimpanan yoghurt di bagian luar kemasan. Suhu penyimpanan yang disarankan biasanya berkisar $1{ }^{\circ} \mathrm{C}-6{ }^{\circ} \mathrm{C}$ atau disimpan di dalam refrigerator $\left(4^{\circ} \mathrm{C}\right.$ ) (Food Drug Administrtion, 2018).
Namun dibalik itu semua terdapat ketidak tahuan akan cara menyimpan yoghurt yang baik sehingga kualitas dan mafaat yang diberikan dalam mengkonsumsi yoghurt tidak didapatkan secara maksimal. Banyak pelaku usaha dan konsumen yang tidak menyimpan yoghurt sesuai pada suhu yang dianjurkan, contoh umum yaitu disimpan pada cool box $\left(15-20^{\circ} \mathrm{C}\right)$, dan pada suhu ruang $\left(25-30^{\circ} \mathrm{C}\right)$. Hal ini didasari oleh ketidak tahuan akan dampak yang dapat ditimbulkan apabila disimpan pada suhu yang salah (Oktavia et al. 20I5). Tujuan yang ingin dicapai pada penelitian ini adalah untuk mengetahui pengaruh suhu dan lama penyimpanyan terhadap gambaran viabilitas BAL yang dilihat dari jumlah ALT BAL serta melihat pengaruh terhadap nilai $\mathrm{pH}$ pada yoghurt

\section{METODE PENELITIAN}

Penelitian ini menggunakan metode penelitian eksperimental dengan rancangan penelitian menggunakan Rancangan Acak Lengkap (RAL) dengan 3 perlakuan berupa perbedaan suhu penyimpanan yaitu suhu $5{ }^{\circ} \mathrm{C}$, $15{ }^{\circ} \mathrm{C}$, dan $25^{\circ} \mathrm{C}$ dengan masing-masing perlakuan suhu akan disimpan selama I hingga 4 minggu lamanya. Untuk mendapatkan hasil perhitungan ALT BAL setelah diberi perlakuan sampel yoghurt diinokulasi kedalam media MRSA dengan metode pour plate yang terlebih dahulu dilakukan tahapan pengenceran hingga $10^{-6}$ dan dilakukan pengulaangan sebanyak tiga kali. Koloni yang tumbuh pada media MRSA kemudian dihitung jumlahnya menggunakan bantuan colony counter, dan dilakukan perhitungan ALT sesuai dengan tingkat pengencerannya. Sedangkan untuk mendapatkan hasil data nilai $\mathrm{pH}$ setelah yoghurt diberikan perlakuan, kemudian dilakukan pengukuran nilai $\mathrm{pH}$ menggunakan alat $\mathrm{pH}$ meter. Sampel yang akan digunakan pada penelitian ini adalah satu jenis drink yoghurt merek $\mathrm{X}$ dengan rasa plain/original. 


\section{HASIL DAN PEMBAHASAN}

\section{HASIL}

Pada penelitian ini sampel yang digunakan adalah yoghurt dengan starter bakteri L. casei. Hasil yang didapatkan pada penelitian ini sesuai dengan karakteristik bakteri L. casei yang memiliki suhu pertumbuhan optimum pada suhu $30-37^{\circ} \mathrm{C}$ dan $\mathrm{pH}$ 5.4-6,4 . Dilihat dari hasil ALT BAL yang diperoleh, pada suhu penyimpanan yang rendah pertumbuhan bakteri L. casei dapat dikendalikan dengan suhu dingin yang menyebabkan pertumbuhannya melambat sehingga nilai ALT relatif lebih stabil. Sebaliknya pada penyimpanan suhu yang lebih tinggi, pertumbuhan $\mathrm{L}$. casei mengalami peningkatan yang sangat cepat dikarenakan semakin mendekati suhu optimal pertumbuhannya. Berdasarkan hasil perhitungan nilai $\mathrm{pH}$ yoghurt, diperoleh nilai $\mathrm{pH} 4,17-4,8$ I. Hasil ini jauh dari nilai $\mathrm{pH}$ optimum bakteri L. casei 5,4-6,4, akan tetapi bakteri ini masih dapat tumbuh dikarenakan karakteristik dari bakteri L. casei yang toleran terhadap asam.

Komposisi yang terdapat dalam yoghurt antara lain air, sukrosa, susu bubuk skim, dekstrosa, dan kultur L. casei. Susu bubuk skim adalah produk susu sapi yang telah diolah menjadi bentuk bubuk yang kemudian menjadi tempat bakteri L. casei hidup dan berkembang. Sukrosa dan dekstrosa merupakan gula dalam bentuk sederhana yang lebih mudah dicerna oleh bakteri L. casei. Dalam proses fermentasi, sukrosa akan dipecah terlebih dahulu menjadi glukosa dan fruktosa agar lebih mudah diproses sedangkan untuk dekstrosa tidak diperlukan kerena merupakan glukosa dalam bentuk yang paling murni. Kemudian dalam proses selanjutnya kedua senyawa tersebut akan difermentasi dan diubah menjadi asam laktat.

Hasil perlakuan suhu dan lama penyimpanan terhadap jumlah ALT BAL terdapat pengaruh yang cukup signifikan. Hal ini dibuktikan pada grafik gambar I. hampir secara keseluruhan terjadi penurunan pada nilai rata-rata mingguan ALT BAL. Pada suhu $15{ }^{\circ} \mathrm{C}$ dan $25^{\circ} \mathrm{C}$ sejak minggu pertama mengalami penurunan secara signifikan dari minggu ke minggu. Akan tetapi, terdapat perbedaan pada suhu $5{ }^{\circ} \mathrm{C}$ di minggu ke-2 yang mengalami peningkatan nilai ALT. Sebagai pebandingan pada suhu $15{ }^{\circ} \mathrm{C}$ dan $25{ }^{\circ} \mathrm{C}$ hanya mengalami peningkatan hingga minggu ke-I dan langsung mengalami penurunan nilai ALT pada minggu ke-2, hal ini disebabkan karena tingginya suhu penyimpanan akan menyebabkan peningkatan pertumbuhan BAL hingga waktu tertentu sampai peningkatan suhu tidak diikuti dengan meningkatnya pertumbuhan (Subagyo et al. 2015).

Berbeda dengan suhu $5{ }^{\circ} \mathrm{C}$ yang masih mengalami peningkatan nilai ALT hingga minggu ke-2, pada suhu rendah aktivitas metabolisme BAL berlangsung secara lambat, mengakibatkan adaptasi bakteri semakin panjang terhadap lingkungannya dan menghambat pertumbuhannya, akan tetapi BAL masih dapat tumbuh hingga waktu tertentu dengan secara perlahan (Danah, et al. 2019). Sesuai dengan teori Oktavia et al. (2015) yang mana pada suhu yang lebih rendah aktivitas bakteri akan menurun sedangkan semakin tinggi suhu penyimpanannya metabolisme BAL berlangsung lebih cepat sehingga mengakibatkan BAL mengalami fase lag dan fase eksponensial, hingga mencapai fase stasioner lalu fase kematian selama penyimpanan.

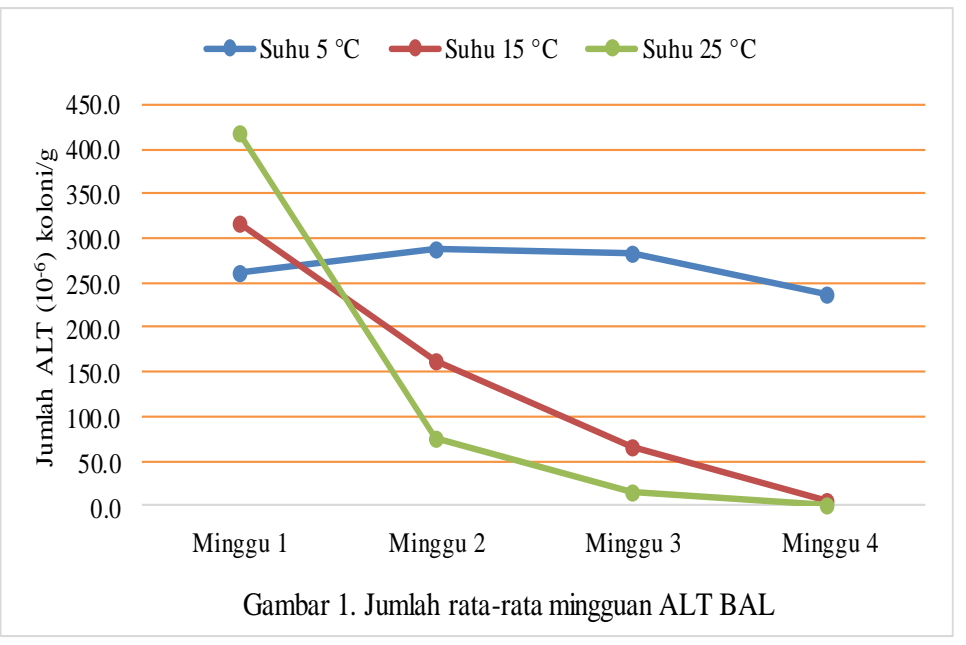




\section{PEMBAHASAN}

Pada grafik gambar I. didapatkan suhu penyimpanan yang paling optimal yaitu pada suhu $5^{\circ} \mathrm{C}$, dikarenakan pada suhu ini memiliki penurunan jumlah ALT yang paling rendah dibandingkan suhu penyimpanan lainnya. Untuk waktu penyimpanan yang paling optimal terdapat pada suhu $5^{\circ} \mathrm{C}$ di minggu ke-2 dengan jumlah ALT BAL 289×106 koloni/gram, hal ini dikarenakan pada minggu ke-2 jumlah ALT BAL berada pada waktu pertumbuhan yang paling optimal sebelum mengalami penurunan pada minggu ke-3. Pada gambar I. dapat dilihat bahwa setelah minggu ke-2 semua perlakuan suhu mengalami penurunan ALT secara terus menerus seiring dengan bertambahnya lama waktu penyimpanan. Semakin lama waktu penyimpanan, maka nutrisi dalam yoghurt yang mana itu adalah sumber makanan dari BAL akan semakin berkurang dikarenakan proses metabolisme yang terus dilakukan oleh BAL itu sendiri dengan secara perlahan (Danah, et al. 2019). Sesuai dengan teori Oktavia et al. (20I5) yang mana pada suhu yang lebih rendah aktivitas bakteri akan menurun sedangkan semakin tinggi suhu penyimpanannya metabolisme BAL berlangsung lebih cepat sehingga mengakibatkan BAL mengalami fase lag dan fase eksponensial, hingga mencapai fase stasioner lalu fase kematian selama penyimpanan.

Pada grafik gambar I. didapatkan suhu penyimpanan yang paling optimal yaitu pada suhu $5^{\circ} \mathrm{C}$, dikarenakan pada suhu ini memiliki penurunan jumlah ALT yang paling rendah dibandingkan suhu penyimpanan lainnya. Untuk waktu penyimpanan yang paling optimal terdapat pada suhu $5^{\circ} \mathrm{C}$ di minggu ke-2 dengan jumlah ALT BAL 289×106 koloni/gram, hal ini dikarenakan pada minggu ke-2 jumlah ALT BAL berada pada waktu pertumbuhan yang paling optimal sebelum mengalami penurunan pada minggu ke-3. Pada gambar I. dapat dilihat bahwa setelah minggu ke-2 semua perlakuan suhu mengalami penurunan ALT secara terus menerus seiring dengan bertambahnya lama waktu penyimpanan. Semakin lama waktu penyimpanan, maka nutrisi dalam yoghurt yang mana itu adalah sumber makanan dari BAL akan semakin berkurang dikarenakan proses metabolisme yang terus dilakukan oleh BAL itu sendiri kehabisan sumber makanannya (Wahyuni et al. 2018).

Berdasarkan hasil perhitungan yang telah diperoleh pada gambar I. dengan merujuk syarat mutu yoghurt menurut Badan Standarisasi Nasional (2009) syarat jumlah bakteri starter dalam yoghurt yaitu 10.000.000 koloni/g. Untuk kualitas yoghurt yang disimpan pada suhu $5{ }^{\circ} \mathrm{C}$ masih memiliki kualitas yang baik dan layak dikonsumsi hingga penyimpanan minggu ke-4 dengan jumlah ALT 237.000.000 koloni/g. yoghurt yang disimpan pada suhu $15{ }^{\circ} \mathrm{C}$ masih memenuhi syarat pada minggu ke-3 dengan jumlah ALT 65.000.000 koloni/g. Sedangkan yoghurt yang disimpan pada suhu $25{ }^{\circ} \mathrm{C}$ memenuhi syarat hingga pada minggu ke-3 dengan jumlah ALT 16.000 .000 kolomi/g. Walaupun pada suhu $15{ }^{\circ} \mathrm{C}$ dan $25{ }^{\circ} \mathrm{C}$ masih memenuhi syarat mutu hingga minggu ke-3 tetap tidak direkomendasikan untuk menyimpan yoghurt pada suhu $15{ }^{\circ} \mathrm{C}$ dan $25{ }^{\circ} \mathrm{C}$ karena sangat berdampak pada kualitas yoghurt dan dapat mengurangi manfaat yang terkandung didalamnya.

Berdasarkan hasil perhitungan nilai $\mathrm{pH}$ pada gambar 2. untuk suhu dan waktu yang paling optimal yaitu pada suhu $5^{\circ} \mathrm{C}$ minggu ke-l, dikarenakan pada suhu dan waktu ini memiliki nilai $\mathrm{pH}$ yang paling tinggi. Tingginya nilai $\mathrm{pH}$ menandakan rendahnya kandungan asam laktat di dalam yoghurt, yang mana apabila kadar asam laktat terlalu tinggi dapat menghambat aktivitas dan kelangsungan hidup dari BAL (Wirawati 2019). Dilihat dari nilai $\mathrm{pH}$ pada grafik gambar 2 . secara keseluruhan terjadi penurunan nilai $\mathrm{pH}$ seiring betambahnya waktu penyimpanan dan semakin rendah sesuai dengan suhu penyimpanannya. Terdapat perbedaan nilai $\mathrm{pH}$ pada setiap perlakuan suhu, ini disebabkan oleh kandungan asam laktat yang meningkat. Semakin tinggi suhu yang digunakan akan 
mempercepat aktivitas metabolisme BAL dalam memproduksi asam laktat dan pada suhu yang rendah metabolisme BAL dalam memproduksi asam laktat akan terhambat atau berkurang.

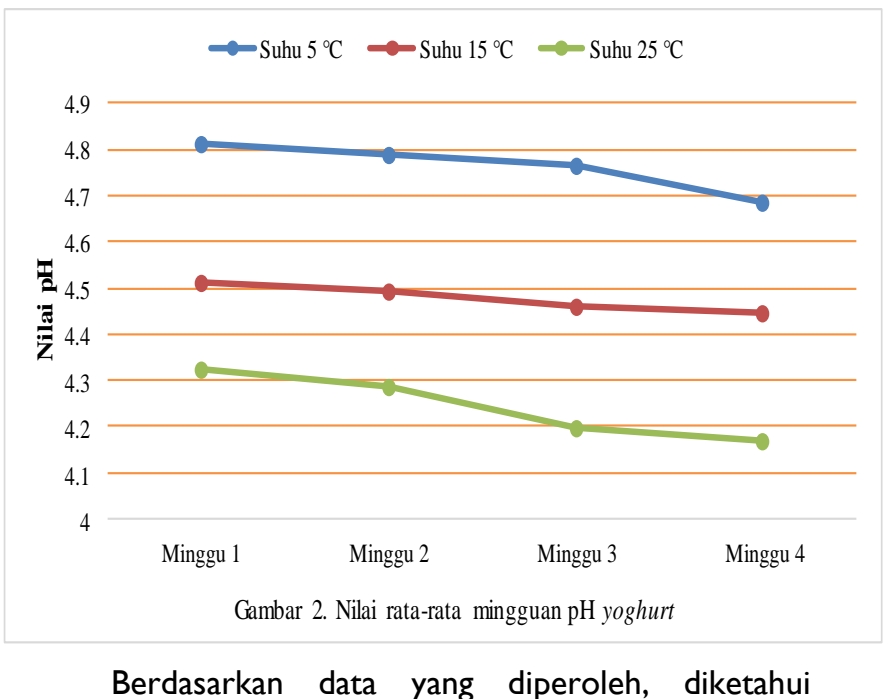

bahwa perhitungan jumlah ALT BAL dan nilai $\mathrm{pH}$ yoghurt saling mempengaruhi pada penyimpanan minggu ke-I. Perbandingan antara gambar I. dengan gambar 2., pada suhu $25^{\circ} \mathrm{C}$ minggu ke-I jumlah ALT $\mathrm{BAL}$ meningkat menyebabkan nilai $\mathrm{pH}$ yoghurt menurun. Menurunnya nilai $\mathrm{pH}$ disebabkan oleh meningkatnya populasi BAL sebagai penghasil asam laktat yang mana asam yang dihasilkan akan menurunkan nilai $\mathrm{pH}$. Kemudian selama proses penyimpanan nilai $\mathrm{pH}$ yoghurt akan selalu berkurang seiring dengan waktu.

Pada penelitian ini sampel yang digunakan adalah yoghurt dengan starter bakteri L. casei. Hasil yang didapatkan pada penelitian ini sesuai dengan karakteristik bakteri L. casei yang memiliki suhu pertumbuhan optimum pada suhu $30-37^{\circ} \mathrm{C}$ dan $\mathrm{pH}$ 5.4-6,4 . Dilihat dari hasil ALT BAL yang diperoleh, pada suhu penyimpanan yang rendah pertumbuhan bakteri L. casei dapat dikendalikan dengan suhu dingin yang menyebabkan pertumbuhannya melambat sehingga nilai ALT relatif lebih stabil. Sebaliknya pada penyimpanan suhu yang lebih tinggi, pertumbuhan L. casei mengalami peningkatan yang sangat cepat dikarenakan semakin mendekati suhu optimal pertumbuhannya. Berdasarkan hasil perhitungan nilai $\mathrm{pH}$ yoghurt, diperoleh nilai $\mathrm{pH} 4,17-4,8$ I. Hasil ini jauh dari nilai $\mathrm{pH}$ optimum bakteri L. Casei 5,4-6,4, akan tetapi bakteri ini masih dapat tumbuh dikarenakan karakteristik dari bakteri L. casei yang toleran terhadap asam.

Komposisi yang terdapat dalam yoghurt antara lain Air, Sukrosa, Susu bubuk skim, dekstrosa, dan kultur L. casei. Susu bubuk skim adalah produk susu sapi yang telah diolah menjadi bentuk bubuk yang kemudian menjadi tempat bakteri L. Casei hidup dan berkembang. Sukrosa dan dekstrosa merupakan gula dalam bentuk sederhana yang lebih mudah dicerna oleh bakteri L. casei. Dalam proses fermentasi, sukrosa akan dipecah terlebih dahulu menjadi glukosa dan fruktosa agar lebih mudah diproses sedangkan untuk dekstrosa tidak diperlukan kerena merupakan glukosa dalam bentuk yang paling murni. Kemudian dalam proses selanjutnya kedua senyawa tersebut akan difermentasi dan diubah menjadi asam laktat.

Berdasarkan hasil perhitungan statistik menggunakan uji ANOVA, dilihat pada tabel 4.7. uji multivariat secara keseluruhan perlakuan suhu dan waktu memiliki nilai $\mathrm{P}<0,05$ atau dapat dikatakan signifikan, sehingga dapat disimpulkan bahwa secara keseluruhan terdapat pengaruh yang signifikan dari perlakuan variasi suhu dan lama penyimpanan terhadap viabilitas $\mathrm{BAL}$ dan nilai $\mathrm{pH}$ pada yoghurt. $\mathrm{Hal}$ ini sesuai dengan penelitian yang dilakukan Oktavia et al. (20I5) yaitu suhu dan lama penyimpanan memiliki pengaruh yang nyata terhadap viabilitas $\mathrm{BAL}$ dan nilai $\mathrm{pH}$ pada yoghurt. Untuk mengetahui pengaruh masing-masing perlakuan terhadap variabel dependentnya dapat dilihat pada tabel 4.8. Tests of Between-Subjects Effects, apabila nilai sig. <0,05 dapat disimpulkan terdapat pengaruh yang nyata terhadap variabel dependent. Pada hasil analisis menunjukkan terdapat pengaruh dari suhu terhadap ALT BAL dan nilai $\mathrm{pH}$ yang dibuktikan dengan nilai sig. $\mathrm{P}<0,05$. Selain itu juga terdapat 
pengaruh dari waktu terhadap ALT BAL dan nilai $\mathrm{pH}$ yang dibuktikan dengan nilai sig. $\mathrm{P}<0,05$.

\section{KESIMPULAN}

Terdapat perubahan viabilitas BAL ditandai dengan adanya penurunan jumlah ALT BAL secara signifikan.

Terdapat pengaruh variasi suhu dan lama penyimpanan terhadap viabilitas $\mathrm{BAL}$ dan nilai $\mathrm{pH}$.

\section{Saran}

Suhu dan waktu yang optimal dalam menyimpan yoghurt yaitu pada suhu $5^{\circ} \mathrm{C}$ selama 2 minggu.

Perlu dilakukan pengujian serupa menggunakan sampel dengan starter BAL yang berbeda..

\section{DAFTAR PUSTAKA}

Aswal, P., Shukla, A., \& Priyadarshi, S. (20I2). Cibtech Journal of Bio-Protocols. Yoghurt: Preparation, Characteristics And Recent Advancements, I(2), 32-44.

Badan Standarisasi Nasional. (2009). SNI 298I Yoghurt. Badan Standarisasi Nasional.

Danah, I., Akhdiat, T., \& Sumarni, S. (2019). Composite. Lama Penyimpanan Pada Suhu Rendah Terhadap Jumlah Bakteri Dan pH Susu Hasil Pasteurisasi Dalam Kemasan, 49-54.

Food Drug Administrtion. (2018). Are You Storing Food Safely? Dipetik oktober 27, 2020,

Oktavia, H. M., Kusumawati, N., \& Kusmawardani, I. (20I5). Jurnal Teknologi Pangan dan Gizi. Pengaruh Lama Penyimpanan Selama Distribusi Dan Pemasaran Terhadap Viabilitas Bakteri Asam Laktat Dan Tingkat Keasaman Pada Yogurt Murbei Hitam (Morus nigra L.), I4(I), 22-3I.

Subagiyo, Sebastian, M., Triyanto, \& Setyati, W. A. (20I5). Ilmu Kelautan UNDIP. Pengaruh $\mathrm{pH}$, Suhu Dan Salinitas Terhadap Pertumbuhan dan Produksi Asam Organik Bakteri Asam Laktat Yang Diisolasi Dari Intestinum Udang Penaeid, 187-194.

Syainah, E., Novita, S., \& Yanti, R. (20I4). Jurnal Skala Kesehatan. Kajian Pembuatan Yoghurt Dari Berbagai Jenis Susu Dan Inkubasi Yang Berbeda Terhadap Mutu Dan Daya Terima, 5(I).

Wahyuni, F., Hartono, A., \& Sari, F. N. (20I8). Jurnal Kesehatan Perintis. Pengaruh Lama Waktu
Simpan Terhadap Angka Escherichia coli Dalam Air Minum Isi Ulang, 5(2).

Wirawati, I. (2019). Pengaruh Lama Penyimpanan Pada Suhu Dingin Terhadap Nilai Ph, Total Asam Dan Jumlah Bakteri Asam Laktat Yoghurt Tepung Suweg (Amorphallus campanulatus). Surakarta: Universitas Muhammadiyah Surakarta.

Wulandari, E., \& Putranto, W. S. (20I0). Jurnal IImu Ternak. Karakteristik Stirred Yoghurt Mangga (Mangifera indica) dan Apel (Malus domestica) Selama Penyimpanan, 10(1), 14-16. 